$$
\begin{aligned}
& \text { كونهاى جديد از سرده قدومه بخش Alyssum (تيره كلميان) از ايران }
\end{aligned}
$$

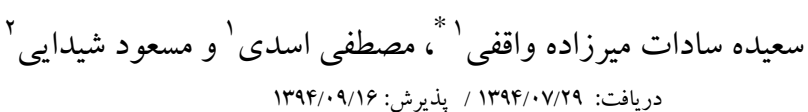

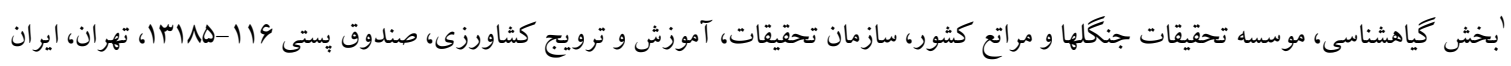

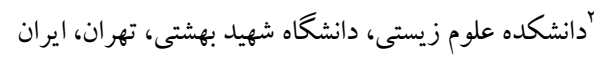

$$
\begin{aligned}
& \text { mirzadeh@ rifr-ac.ir مسئول مكاتبات }
\end{aligned}
$$

A. جكيده. نمونه هايى قابل توجه از مناطق جنكلى كجور، بين لشكناره و گنديس كلاى استان مازندران جمع آورى گرديد كه شباهتهاى زيادى با گونه

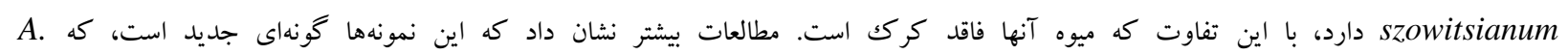

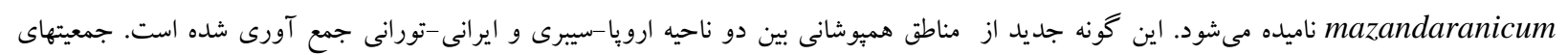

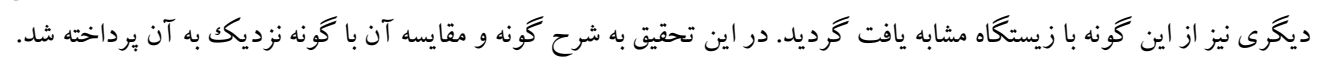

وازههاى كليدى. استان مازندران، جِييائيان، شمال ايران، گونه جديد

\title{
A new species of the genus Alyssum section Alyssum (Brassicaceae) from Iran
}

\author{
Saeedeh Sadat Mirzadeh Vaghefi ${ }^{1 *}$, Mostafa Assadi ${ }^{1} \&$ Masoud Sheidai $^{2}$ \\ Received: 21.10.2015 / Accepted: 07.12.2015
}

\author{
${ }^{1}$ Department of Botany, Research Institute of Forests and Rangelands, Agricultural Research Education and Extension \\ Organization (AREEO), P. O. Box 13185-116, Tehran, Iran \\ ${ }^{2}$ Department of Biology, Shahid Beheshti University, Tehran, Iran \\ *Correspondent author: mirzadeh@rifr-ac.ir
}

\begin{abstract}
Specimens collected from the forest areas of Mazandaran Province (Iran), Kojour, between Lashkenareh and Gandis-Kala village showed significant characteristics. At first glance, these specimens looked similar to $A$. szowitsianum, but with no indumentum on fruit. Further studies showed that those specimens belong to a new species, Alyssum mazandaranicum Mirzadeh \& Assadi sp. nov., which was confined to the ecotone area between Euro-Siberian and Irano-Turanian regions. More populations of this new species were also found in other localities with similar ecological circumstances. Here, the new species is described, illustrated and compared with the closest taxon.
\end{abstract}

Keywords. Alyssum, Cruciferae, Mazandaran province, N. Iran, new species

\section{INTRODUCTION}

The Brassicaceae family comprises 49 tribes, 321 genera, and 3660 species, of which 20 genera and 34 species remain to be assigned to tribes (AlShehbaz, 2012). Genus Alyssum consists of about 170-195 species worldwide, native to Europe, Asia and northern Africa (Al-Shehbaz, 1987; Appel \& Al-Shehbaz, 2003; Warwick et al. 2006; Li et al., 2014). Most of its species grow on rocky slopes in arid regions. 28 species and 7 varieties were introduced in Iran (Rechinger, 1968). Later, A. stipitatum Kavousi \& T.R.Dudley, A. mozaffarianii Kavousi and A. hezarmasjedense Kavousi \& Nazary were described (Kavousi, 2001; Kavousi et al., 2014).

Comprehensive taxonomic studies of Alyssum in Iran are rare; therefore, the first author started a 


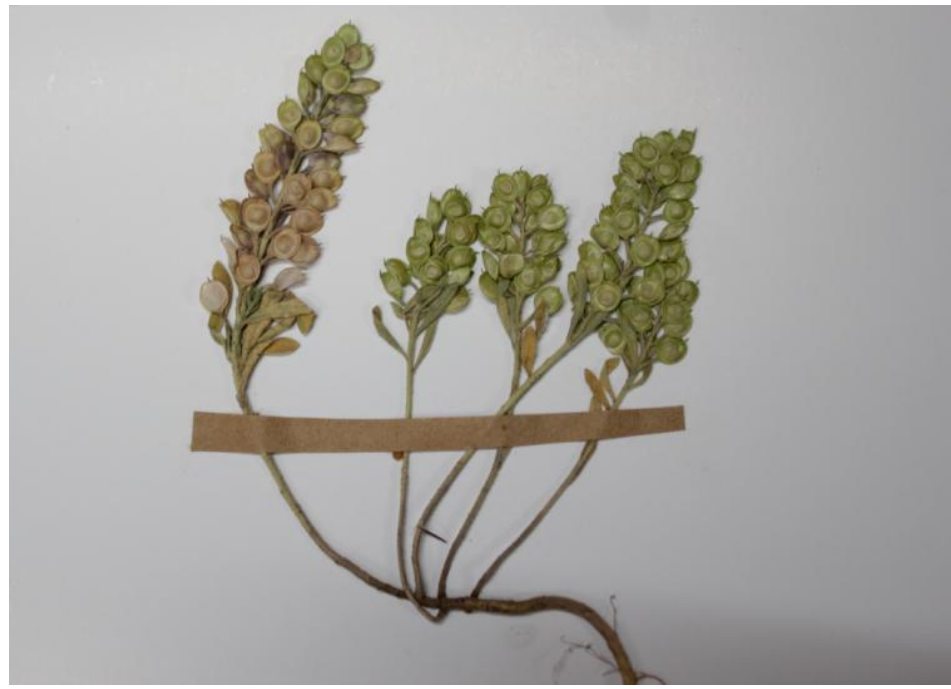

Fig. 1. Plant on sheet of Herbarium (A. mazandaranicum).
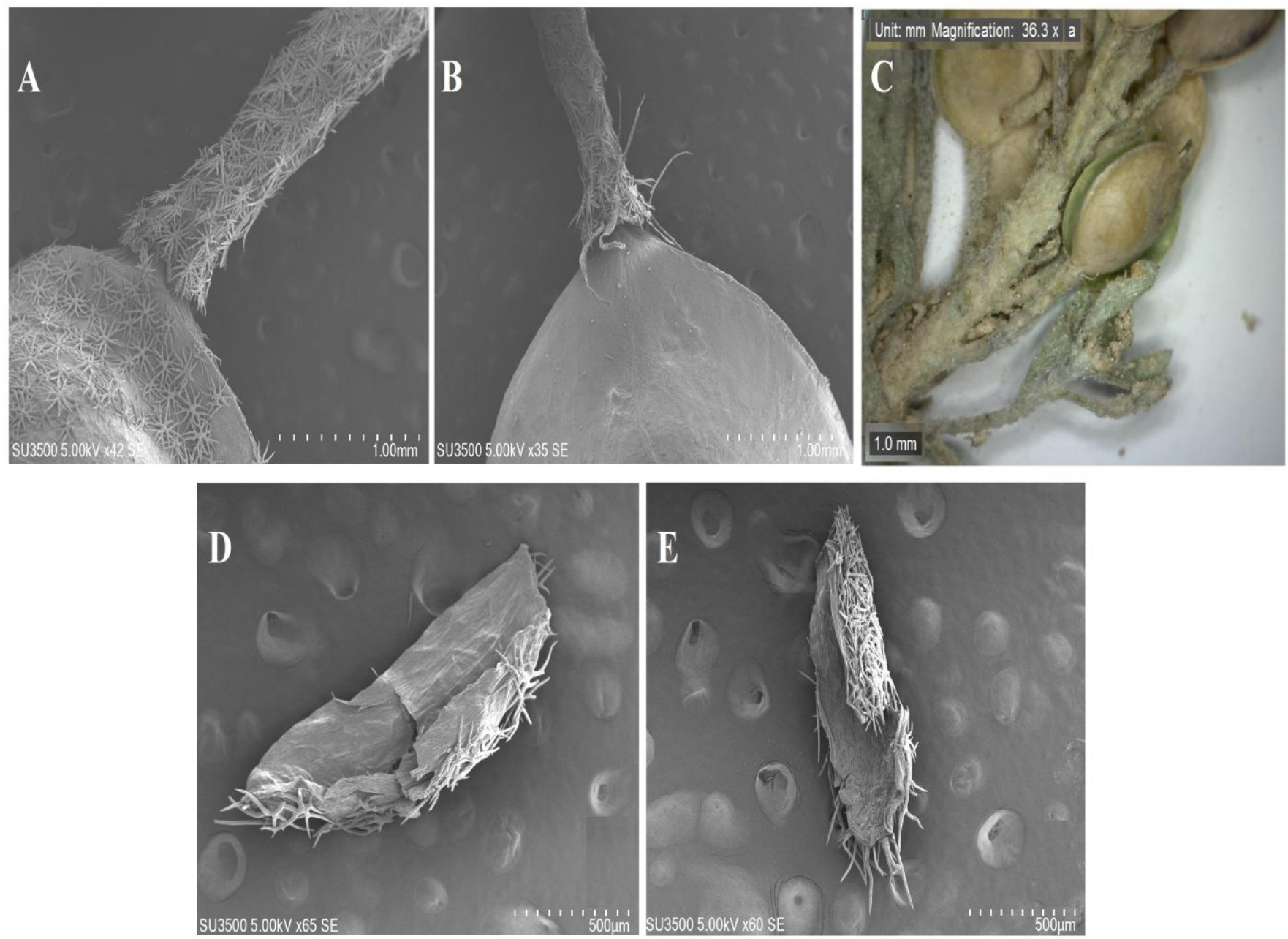

Fig. 2. A: Silicule of A. szowitsianum; B: Silicule of A. mazandaranicum; C: Inflated Pedicel of A. mazandaranicum; D: Sepals (A. szowitsianum); E: Sepals (A. mazandaranicum).

taxonomic revision of the genus in Iran in the framework of a Ph.D. research project. Herbarium specimens from large herbaria in Iran (TARI, IRAN) and the Natural History Museum of Vienna (W) were also studied.
In addition, excursions to different parts of Iran to collect new specimens and field observations were made. This paper aims to describe the new species and compare it with the close affinities. 


\section{MATERIAL AND METHODS}

The new species was first collected in 2012 by the first author from the higher areas of forests in Kojour, between Lashkenareh and Gandis-Kala villages, Mazandaran Province, Iran. Fifteen individuals' were collected from this location. Flora Iranica (Rechinger, 1978), Flora of Turkey (Dudley, 1965), Flora of Iraq (Townsend \& Guest, 1980), Flora of the USSR (Bush, 1939) and Flora Europaea (Dudley \& Ball, 1964) were used to compare the new species with the taxa reported by them.

All specimens of TARI and IRAN were examined. Two other populations of the species were also found among unidentified materials. Characteristics of this species were compared with those of $A$. szowitsianum Fisch. \& C.A.Mey. as its closest affinity.

The samples were examined with a binocular microscope and Planapo lens at 7.5 X to $64.5 \mathrm{X}$ magnifications. Silicules and pedicels of dry samples were selected for scanning electron microscopy (SEM). They were mounted on the stubs using double-adhesive tapes and coated with goldpalladium. Coated specimens were viewed with a SU 3500 Electron microscope at $15 \mathrm{kv}$.

\section{RESULTS AND DISCUSSION}

Remarkable morphological characters of the new species include its glabrous silicule with inflated pedicels, 2 seeds in each silicule, petals clearly exceeding from the sepal, and monomerphic sepals. These characters indicate that the new species belong to the Alyssum sect. Alyssum. Among the species of this section A. szowitsianum is the closest affinity.

\section{Taxonomy}

Alyssum mazandaranicum Mirzadeh \& Assadi, sp. nov. (Figs.1, 2)

Typus. Iran, Mazandaran province, Kojour, between Lashkenareh and Gandis-Kala villages, higher areas of forest with scattered trees, 1158 m,12.06.2012, Mirzadeh 101593 (holotypus TARI!, isotypi T!, W!).

Species nova differt a A. szowitsianum siliculis glabris (non pilis stellatis), sepalis linearis (non ovatis), stylis glabris (non ad basem pilosis). Annual, 5-9 cm high, branched from the base, ascending, stellate hairy. Leaves oblanceolate, linear or spathulate, $1-1.3-\times 0.2-0.3 \mathrm{~cm}$, stellate-hairy.
Racemes elongating in fruit, 2.5 to $4 \mathrm{~cm}$ long. Pedicles in fruiting stage $3-4 \mathrm{~mm}$ long, stellatehairy with unequal rays, inflated, slightly spreading.

Sepals linear, $1.5-1.7 \times 0.5 \mathrm{~mm}$, membranous at margin, deciduous, stellate-hairy. Petals long cordate, sometimes narrowed at the middle, yellow, sparsely hairy on the upper surface, glabrous below. Long filaments $1 \mathrm{~mm}$ long, entire or unilaterally toothed above the middle; short filaments 0.7 $\mathrm{mm}$ long, toothed above the middle.

Ovary with 2 ovules in each loculus. Silicule 4×3-3.5 mm, elliptic-ovate, inflated on one side, flat on the other side, truncate or emarginated at the apex, often 2 seeded, glabrous. Nectar gland long. Style 0.5-0.7 mm. long, broad at base. Seeds $1.5-1.7 \times 1.2-1.5 \mathrm{~mm}$, wingless or with narrowly winged.

Etymology. Specific epithet refers to the province Mazandaran (Iran), where type specimens were collected.

Other specimens studied. Iran. Gilan province, Asalem to Khalkhal, Kerman village, Moradi 102832 (TARI); Azarbayejan province, Arasbaran protected area, Mahmoodkaghi, above EbrichJadid, Hamzeh'ee \& Asri 81416 (TARI).

Distribution. The new species is endemic to transitional areas between Euro-Siberian and Irano-Turanin regions in Iran (Fig. 3).

Ecology. The new species grows in an open forest with scattered trees of mainly Fagus orientalis Lipsky and Ulmus glabra Hudson.

Chromosome number. The chromosome number of this species is determined to be $2 n=4 x=32$ $(\mathrm{x}=8)$ (Fig. 4).

A. mazandaranicum is closely related to A. szowitsianum, but with spreading pedicles, elliptical silicules, shape and size of petals, style size, seed size, 2 ovulate loculus and apical placentation.

The two species may be readily distinguished on sepal morphology, leaf size, silicule size and indumentums, nectar glands, pedicel trichomes, chromosome number and geographical distribution, as summarized in Table 1. 


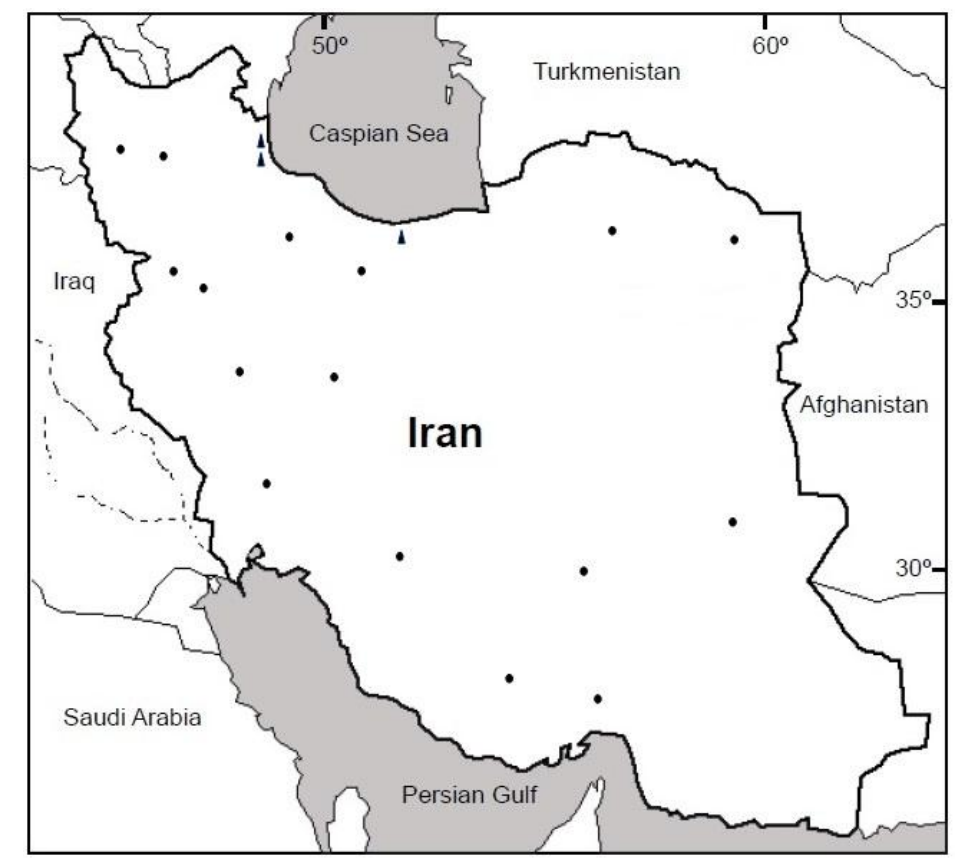

Fig. 3. Distribution of Alyssum szowitsianum (४) and A. mazandaranicum (४) in Iran.

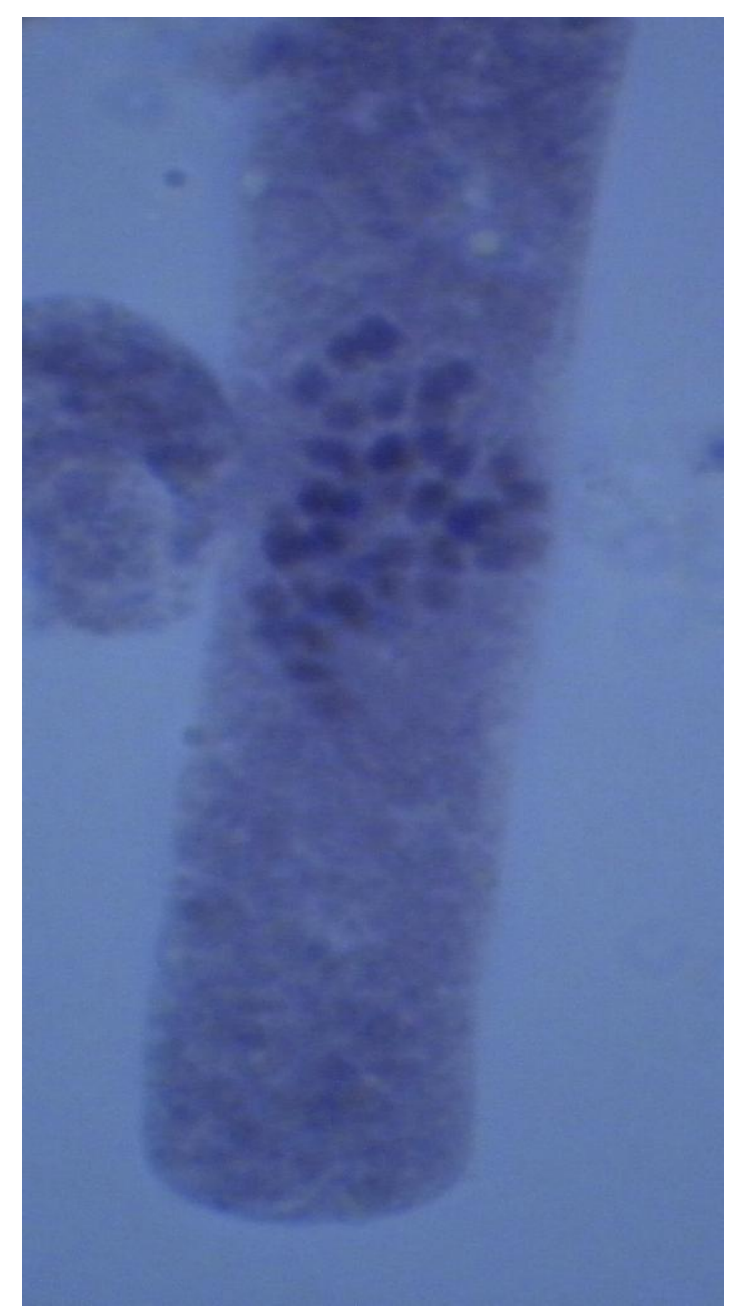

Fig. 4. Chromosome number of A. mazandaranicum $(2 \mathrm{n}=32)$. 
Table 1. Comparison of morphological characteristics between A. mazandaranicum and A. szowitsianum.

\begin{tabular}{|c|c|c|}
\hline & A.mazandaranicum & A. szowitsianum \\
\hline Leaf & $\begin{array}{l}\text { Linear, spathulate and } \\
\text { oblanceolate }\end{array}$ & Oblanceolate \\
\hline Leaf size $(\mathrm{mm})$ & $10-11 \times 2-3$ & $13-40 \times 2.5-8$ \\
\hline Petal Size $(\mathrm{mm})$ & $1.2-2 \times 0.2-0.7$, long & $1.5-1.7 \times 0.5$, long \\
\hline Shape & cordate & \\
\hline Sepal form & Linear & Ovate \\
\hline Style size $(\mathrm{mm})$ & $0.5-0.7$ & $0.5-1$ \\
\hline Silicule & Glabrous, elliptic-ovate & Hairy, elliptic \\
\hline Silicule size $(\mathrm{mm})$ & $4 \times 3-3.5$ & $3.5-5 \times 3-4.5$ \\
\hline Ovulate loculus & 2 & 2 \\
\hline placentation & apical & apical \\
\hline Style & Glabrous & Hairy at base or glabrous \\
\hline Pedicel & Spreading and Swollen & Spreading and Swollen \\
\hline $\begin{array}{r}\text { Trichomes of } \\
\text { pedicel }\end{array}$ & With unequal rays & With equal rays \\
\hline Seed size $(\mathrm{mm})$ & $1.5-1.7 \times 1.2-1.5$ & $1.2-2 \times 1-1.5$ \\
\hline $\begin{array}{l}\text { Geographical } \\
\text { distributions }\end{array}$ & $\begin{array}{l}\text { North of Iran (Mazandaran \& } \\
\text { Azarbayejan provinces.) }\end{array}$ & Mostly in center and south of Iran \\
\hline Nectar glands & Long & very short \\
\hline Chromosome number & $2 n=32$ (Fig. 4) & $\begin{array}{l}\mathrm{n}=8,2 \mathrm{n}=16 \text { (Ghahremaninejad } \text { et al., } \\
\text { 2013; Aryavand,1975) } 2 \mathrm{n}=14 \\
\text { (Ghahremaninejad } \text { et al., 2013; } \\
\text { Bolourian } \text { et al., 2011) }\end{array}$ \\
\hline Floristic region & $\begin{array}{l}\text { Transitional area of Irano-Turanian } \\
\text { and Euro-Siberian Regions }\end{array}$ & Irano-Turanian region \\
\hline
\end{tabular}

\section{ACKNOWLEDGEMENT}

The authors would like to thank the curators of the herbaria TARI, IRAN and W for making facilities to study the herbarium specimens. We are also grateful to Dr. A. Falatoury and Miss. A. Shamekhi for preparation of the illustrations.

\section{REFERENCES}

Al-Shehbaz, I.A. 1987. The genera of Alysseae (Cruciferae;Brassicaceae) in the Southeastern United States. - J. Arnold Arboretum 68: 185240.

Al-Shehbaz, I.A. 2012. A generic and tribal synopsis of the Brassicaceae (Cruciferae). - Taxon 61(5): 931-954.

Appel, O. and Al-Shehbaz, I.A. 2003. Cruciferae. In: Kubitzki K. and Bayer C. (eds.). The families and genera of vascular plants 5: 75174. - Springer, Berlin.

Aryavand, A. 1975. Contribution a I'étud cytotaxonomique de quelques Cruciferes de 1'Iran et de la Turquie. - Bull. Soc. Neeucháteloise Science Nature 98: 43-58.
Bolourian, S., Tavassoli, A. and Pakravan, M. 2011. In: Kamari, G., Blanche, C. and Siljak Yakovlev, S. (eds.): Chromosome number reports 21. - Flora Mediterranean 21: 355-376.

Bush, N.A. 1939. Alyssum. - In: Komarov V.L. (ed.). Flora of the U.S.S.R. 8: 340-359. - Izdatel'stvo Akademii Nauk SSSR, Moskova-Leningerad.

Dudley, T.R. 1965. Alyssum. In: Davis P.H. (ed.). Flora of Turkey 1: 362- 409. - Edinburgh Univ. Press, Edinburgh.

Dudley, T.R. and Ball, P.W. 1964. Alyssum. In: Tutin, T.G., Heywood V.H, Burges, N.A. Valentine, D.H. Walters, S.M. and Webb, D.A. (eds.) Flore Europaea EWD 1: 297-304. Cambridge University Press, Cambridge.

Ghahremaninejad, F., Nejad Falatoury, A., Mahmoodi, M., Fereidounfar, S. and Hoseini, E. 2013. Plant Chromosome Book of Iran. House of Biology, Tehran. 194 pp.

Kavousi, K. 2001. Notes on the plant family Crucifera in Iran, new taxa and new records. - Iran. J. Bot. 9(1): 47-54.

Kavousi, K., Nazary, Z. and Ghahremaninejad, F. 2014. A new species of Alyssum (Brassicaceae) from Northeastern Iran. - Novon 23(1): 59-61. 
Li, Y., Kong, Y., Zhang, Z., Yin, Y., Liu, B., Lv, G. and Wang, X. 2014. Phylogeny and biogeography of Alyssum (Brassicaceae) based on nuclear ribosomal ITS DNA sequences. - J. Genetic 93(2): 313-323.

Rechinger, K.H. 1968. Alyssum. - In: Rechinger, K.H. (ed.) Flora Iranica vol. 57: 146-170. Akademische Duck und Verlagsanstalt, Graz.

Townsend, C. and Guest. E. 1980. Alyssum. In: Townsend, C. and Guest, E. (eds.) Flora of Iraq, 4(2): 959-984. - Ministry of Agriculture \& Agrian Reform Republic of Iraq, Baghdad.

Warwick S.I., Francis, A. and Al-Shehbaz, I.A. 2006. Brassicaceae: Species checklist and database on CDROM. - Plant Syst. Evol. 259: 249-258.

$* * * * *$

Mirzadeh Vaghefi, S.S., Assadi, M. and Sheidai, M. 2016. A new species of the genus Alyssum section Alyssum (Brassicaceae) from Iran. - Nova Biol. Reperta 3 (2): 145-150. 